\title{
A Note on Sources
}

T $\mathrm{n}$ this study of electioneering rhetoric in the press, I felt I should convey a representative sample of the language from as many newspaper sources as possible. A century of sources in two countries forced me to be selective. I have attempted, however, to choose newspaper sources from areas in both the United States and Britain that experienced regular competitive elections. For the most part, the newspapers quoted are ones that survived at least twenty years and had consistent party allegiance for long periods of time. I also tried to select cities with two or more newspapers expressing different party affiliations. This criterion sometimes meant concentrating on the biggest cities in the two countries, particularly New York and London. Since this work is mainly concerned with the interaction of parties and editors on the one hand, and voters on the other, I have drawn most of my sources from the month immediately preceding presidential elections in the United States and general elections in Britain. To be faithful to particular forms of rhetorical speech, I have occasionally used extended quotations.

This book concentrates on the rhetoric of the partisan press. Independent newspapers and yellow journals have been included, but the majority of citations come from the party press. In determining which newspapers were partisan, I have relied on 
standard reference works and monographs to aid my own judgment. ${ }^{1}$ I have quoted extensively from the two best-known "newspapers of record": The Times of London and the New York Times Despite their protestations of "independence" in the nineteenth century, the partisanship of these two newspapers at election time was often unmistakable.

Some of the best political rhetoric I have been forced to leave out: I have largely omitted electioneering in Ireland and in the Lower South before the Civil War. The political context in these two regions was so exceptional that I concluded it would require too much explanation to incorporate many examples. The language of the South after the Civil War increasingly resembled the rest of the United States. I have thus included examples from many southern newspapers in the Gilded Age chapter without the necessity of additional explanations. Why the South, especially the Lower South, persisted in employing laudatory rhetoric until the eve of the Civil War is an engaging question. Oral performance by the gentry and oral protest by the populace carried far more weight in a political culture that had lower rates of literacy. Newspapers in the South did not achieve the same circulation or the same influence enjoyed by newspapers in the North and West until after the Civil War. Ireland also had a tradition of oral protest that seemed to carry more weight in its political culture in the nineteenth century. Southern Irish oral culture included the Celtic language tradition, despite the rapid disappearance of Irish as a spoken language. To offer an adequate explanation for the "otherwise-mindedness" of the American South and Ireland would mean a four-way comparison and a different sort of book than the one I have written.

In a work that addresses the visual dimension of newspaper appeals, I have strived as much as possible to reproduce the

${ }^{1}$ Arthur Aspinall, Politics and the Press, c. I $780-1850$ (London, 1949); Stephen Koss, The Rise and Fall of the Political Press in Britain (London, 1981 ), vol. 1 ; Clarence S. Brigham, History and Bibliography of American Newspapers, I690-1920, 2 vols. (Worcester, Mass., 1947); Culver H. Smith, The Press, Politics, and Patronage: The American Government's Use of Newuspapers, I789-1875 (Athens, Ga., 1977); Thomas C. Leonard, The Power of the Press: The Birth of American Political Reporting (New York, 1986); Michael E. McGerr, Decline of Popular Politics: The American North, I865-1928 (New York, 1986). 
actual layout and typeface of the original source. The use of large type, small type, italics, and boldface has been recorded and reproduced on the page to convey the visual impact of the original. Another important form of visual communication was the political cartoon. Reproduced in this book are only a few of the large number of cartoons, caricatures, and broadsides from more than a century of political satire. These are only meant to suggest the larger body of sources. 

The Language of Democracy 
